UDC $81-13$

DOI: $10.17223 / 24109266 / 7 / 6$

\title{
THE FORMATION OF PROFESSIONAL FOREIGN LANGUAGE COMPETENCE AS AN INTEGRAL PART OF THE CULTURAL BACKGROUND OF NEW GENERATION RUSSIAN ENTREPRENEURS
}

\author{
T.P. Kamaeva, N.N. Kazaeva, M.V. Zolotova, E.V. Ganyushkina \\ Nizhny Novgorod State University (Nizhny Novgorod, Russia). \\ E-mail: mviazolotova@gmail.com; natkaz50@mail.ru; elenaganyushkina@gmail.com
}

\begin{abstract}
The purpose of this paper is to highlight the importance of professional foreign language competence as part of entrepreneurs' cultural background in today's Russia. The article focuses on improving the education of Russian businesspeople through the integration of a professional foreign language course and the disciplines of their university major. The authors examine their own experience in searching for the most effective teaching tools, self-study evaluation tools including. The outcomes gained indicate that the modular interdisciplinary design of suggested training courses may have a positive impact on entrepreneurs' job performance.

Keywords: entrepreneur; cultural background; professionally-oriented interdisciplinary courses; foreign language competence; integration; teaching technologies; self-study evaluation tools.
\end{abstract}

\section{Introduction}

Reforming the Russian economy [1: 239] has laid the foundation for domestic enterprise development, the success of which, to a large extent, depends on entrepreneurs - the innovative owner-managers who create some new product or service or suggest a better way of using existing products or services. They are the first risk takers who think up ways to satisfy people's needs [2: 669]. It is they who invest money, time, and effort in organizing and managing a firm; run the risk of failure; and reap the rewards of success. They are willing to exploit new opportunities and are driven by a passion to succeed [3: 611]. To stay abreast of market changes they have to exert themselves so as to use their abilities to interact with current and potential customers, partners, and competitors. In view of this, creativity must become a norm of present-day entrepreneur professional training.

In a globalized world with a large number of multinational firms there is an urgent need for a common working language [4-6]. Today's entrepreneur has to acquire a foreign language in order to be a successful member of such a business team. Currently, a new vision of foreign language fluency involves the formation of a professional language competence. So, it is evident that only people with a certain cultural background and a high level of 
professional training with the necessary foreign language competence can be successful in the multifaceted world of entrepreneurship.

Nowadays almost every educated Russian businessperson is a state university graduate. The question arises as to whether Russian university education is aimed at achieving the necessary professional competences that enable entrepreneurs to be competitive in the globalized world.

The purpose of this paper is to analyze Russian university education experience and to stress the necessity of training specific entrepreneurial skills. The given article argues the possibility of teaching a "Foreign Language" course as a way to raise the level of professional culture. In this connection, the article suggests how to achieve the formation of business language competence as part of entrepreneurial culture. It also gives some recommendations on the interaction of a foreign language course with the major disciplines on the one hand and the creation of professionally-oriented courses delivered in a foreign language on the other.

\section{Materials and methods: teaching experience}

\section{Present-day Russian reality and teaching goals}

Every modern business higher educational establishment trains people to become capable of meeting the demands of market economy and its graduates, would-be entrepreneurs in particular, ought to comply with the present-day requirements formulated as competences in new Russian Federal educational standards. In other words, a businessperson should be able to generate new ideas, search for useful information and speak out his / her point of view both in native and foreign languages, work in a team (an international one including), be aware of overseas business culture peculiarities, keep at the forefront of innovation and learn throughout their life. All these competences seem to be constituent parts of their cultural and business proficiency which need to be trained [7: 128]. In this, Russian university instructors agree with their foreign counterparts [8; 9: 284]. However, it should be stressed that Russian reality makes the university staff pay special attention to developing a foreign language competence as Russia is becoming part of the entire world where almost everybody knows some other languages besides his / her mother tongue. Hence, learning a foreign language has become very popular these days and the challenge to foreign language teachers now is to make language classes more effective.

However, the above-mentioned professional skills and foreign language competence are not always enough to be well-equipped for global business. It is known that discussions between business partners from different countries rather often break down for lack of cultural understanding. 
Thus, training in intercultural awareness should be part and parcel of Russian higher education as well. Cultural competence, at that, is looked upon as part of foreign language competence together with such competences as linguistic, sociolinguistic, cognitive, and the like. All of them are needed in order to achieve successful communication between business representatives of different cultures. As it can be seen from many studies of scholars [10: 416; 11: 1308], it is cultural competence that seems to be the cornerstone of successful communication because culture is really a key part of the integration between language and thought [12].

The study of the present-day situation in Russia, namely the analysis of business experience presented in a number of articles of domestic business representatives [13: 126-132; 14], as well as the survey of higher school graduates' opinion on business practice reveal a certain gap between society needs and the higher school vocational education process. It is regrettable to note that a Russian higher school graduate does not always achieve the necessary skills to the full. For instance, he / she does not speak a foreign language to such an extent that could let him / her be an active participant of international professional interaction. Inadequate foreign language skills are sure to prevent fruitful business communication. Besides, he / she hardly ever uses acquired knowledge and skills from different professional subjects properly for lack of interdisciplinary experience in particular. All this combined does not give them a competitive advantage in today's tough job market and, consequently, limits his / her ability to keep abreast of the time.

\section{Urgent changes needed}

There is a general agreement both in domestic and overseas higher business schools that reforms in university training are essential [1: 239; 15: 149170]. In a way, new Russian federal state standards of higher education reflect the current social demands with the emphasis on the formation of professional competence, namely an individual's ability to use knowledge, skills and personal business qualities when solving professional problems [16, 17]. It means that teaching all disciplines in a business higher school, including a foreign language, should be professionally-focused. A future entrepreneur, first and foremost, strives to master his / her profession and looks upon a foreign language as a means of professional communication in an intercultural environment.

The very idea is not new. But at present, a professionally-directed approach to teaching a foreign language seems to be of particular importance. It is so because the interests of the state and globalization of business require the acquisition of a professional foreign language, a business one in question. So, it must be stressed that a foreign language teaching should be correlated with entrepreneurs' occupation. Besides, the training materials should 
reflect the specific logic of the disciplines that form the essence of entrepreneurial activity.

In addition, intensive implementation of innovative technologies could foster the process of training and the university teacher ought to use educational training technologies that take into consideration the professional orientation of their students. What is more, the successful teaching of a professional foreign language needs joint efforts of a training team consisting of a professor responsible for nucleus professional disciplines in the curriculum and a highly-qualified foreign language teacher. It would also be a good idea to cooperate with a guest entrepreneur-lecturer - preferably a native foreign language speaker. They participate in the teaching process translating their experiences with business phenomena into the classroom. This cooperation might not necessarily be face to face, doing it online is quite appropriate. Hopefully, the input students receive from such meetings can result in increasing their motivation to master a foreign language.

\section{Our interdisciplinary experience}

Our teaching interdisciplinary experience, short as it is considering the time span, shows that the formation of a foreign language competence as part of a professional cultural background in today's globalised world implies some changes in the mode of teacher's thinking. Seemingly, modern professional courses should be interdisciplinary-oriented to meet the demands of a present-day country's economy. Next, the programs for these courses should be preferably project-based so as to facilitate the learners' mastering the material which is going to become part and parcel of their professional cultural background, for one thing, and, for the other, to foresee the necessity of possible teamwork in the future. Last but not least, a professionally-directed approach in teaching is to become dominant while other approaches, namely "student-centered", "activity-oriented", "communicative", "cognitive", should be looked upon as parts of this approach.

Apparently, the formation of a foreign language competence cannot be the same during different study periods. Younger students can be given the fundamentals of their major in a foreign language. The courses like "A Foreign Language for an Entrepreneur", "A Foreign Language for Lawyers in Small Business" seem to enjoy popularity with the junior students. As for undergraduates, they show interest in professional disciplines conducted in a foreign language, among them are "Corporate Social Responsibility: Global Experience", "Comparative Law", "Tourism and Hospitality Business", "International Marketing", etc.

For these disciplines to be most successful, it is advisable to design them by an international team of instructors. Namely, in Nizhny Novgorod Lobachevsky University such a course ("Comparative Law") has been de- 
veloped by a team of professors consisting of a Russian professor of comparative law, a Russian foreign language teaching specialist and an American doctor of jurisprudence. Evidently, such an interaction in creating a course helps to build it in line with international educational standards. Moreover, courses like that are an example of integration between professional disciplines and a professional foreign language course which promotes the formation of professional competences needed by a Russian entrepreneur. In fact, a foreign language instructor helps a learner not only to master his major through a foreign language but also introduces different ways to anticipate and overcome intercultural barriers which are significant when dealing with foreign partners though participants may not be always aware of these barriers.

\section{Thought-provoking teaching materials}

Every component of the suggested interdisciplinary, project-based professional course should be created in a new way and, so to say, from a different angle. The size of this article limits the description of all components of the above-mentioned course; therefore we are going to focus on its key constituents. Teaching materials, in our opinion, seem to be most essential; they are prior to other components. Unlike the teaching materials designed for traditional university courses, the teaching materials in question should have a number of specific characteristics. They are projectoriented from beginning to end and are not restricted only to one professional sphere as usual; it means that students are to sort out information from different areas of knowledge relevant for the required project and give reasons for their choice. In most cases the materials imply student teamwork because the majority of projects are made through cooperation which appears to become "a bottleneck" in some occasions. Another important feature of the described teaching materials is their problematic, thought-provoking character. Compared with traditional materials problematic ones contain a problem not only in the given situation and the offered tasks but provoke the necessity to search for alternative means of solving the stated problem. Besides, created teaching materials should be aimed at independent student work which is the basis of learning. A student is encouraged to find additional ways to reach the formulated goals and, importantly, these ways have not been foreseen by the teacher. Learners receive extra scores for being that creative.

As teaching practice shows, it is not sufficient to create the necessary material, the way to organize it proves to be crucial for learners' activities too. Modular structure is one of the preferable ways of organizing the teaching materials online, and it allows the teacher to guide and assess student progress step by step. Thus, it can foster and encourage learning. Eve- 
ry module might include a certain number of components: "a mind plan" (a way to identify the main topic areas); subject-specific concepts / notions from different business areas needed to be considered when working on the project; a glossary of Russian and foreign professional terms; training exercises; a case study; some creative tasks that involve learners in an independent search of materials to complete them; input and final tests; evaluation criteria; a list of recommended literature and reference materials, web sites including.

The modules discussed are organized as a system; nevertheless, they can be looked upon as separate independent unit components in the learning process. A student has an opportunity to learn unit after unit or choose those units, which are of greater interest to him / her. Moreover, since each component of a module is given at different levels of difficulty (e.g. basic, preintermediate, intermediate), the material may be customized according to the interests of learners in mixed-ability groups. Every student moves from one module to another and builds their own course of studies.

Summarizing our ideas about the needed teaching materials, it may be stated that if they comply with the preceding requirements, training is more likely to become fruitful for a good reason. The appropriate teaching materials may promote students' creativity and enable them to become thinkers and doers.

\section{University teacher and teaching technologies}

Learners are in search of two things: appropriate teaching materials and a competent and creative teacher, both of which address their varying needs. Since higher school teaching is undergoing big changes in the professional training of would-be entrepreneurs, the role of a university teacher cannot remain unchanged. Nowadays, a university teacher is supposed to become a team player working closely with Russian and foreign colleagues responsible for professional disciplines. As for a foreign language teacher, his / her role is specific because it is this very teacher who enjoys profound knowledge of different cultures - both native and foreign - and so can adequately teach how to overcome cultural differences in professional communication.

Professional competences, including foreign language competence, can be achieved more effectively if the educational process simulates real business activities. There are a few teaching technologies that facilitate professional education and seem to be efficient in meeting professional objectives [18: 432; 19: 164]. What is more, they can easily fit in with any educational environment. Among them are: cooperative learning, case study, project designing, information technologies, etc.

To take an example of how case study technology has been used, let us look at one of the tasks aimed at developing students' case analyzing 
skills in the interdisciplinary "International Marketing" course. A real-life case concerning sales decrease of bottled water "Sarov" on the local market was offered to the students. They were supposed to study the background of the case, the present-day positioning of the product on the market and its customer popularity. Their task was to present ideas how to improve sales. The solution to the problem involved considering some key factors: the product itself (its quality and design: the taste of water, the form and material of the bottle, its size and label, etc.); targeted group of customers (age, occupation, etc.); the current situation on the local market (its market share, product availability: supermarkets, health food shops, convenience stores; price, competitors, etc.); product advertising (commercials, leaflets, mail order, etc.). To do the task, the students were to work in teams and certain time limits were set. As a result of their activity, they were to design a sales leaflet for the campaign to relaunch "Sarov" bottled water. The leaflet composed should attract attention and communicate the reasons why people should buy this water. It should also include a slogan. The students' work was evaluated and commented on not only by teachers but also by business practitioners and other student teams. Importantly, the additional activity of every team student done on their own was evaluated as part of his / her total mark. Needless to say, every work stage of the students was monitored and graded by the instructors to be given proper weight in the total assessment. Self-study skills - the most needed ones to keep at the forefront of innovation - can also be gained this way.

\section{Outcomes Evaluation}

Evaluation is an essential part in the learning process. It helps the learners recognize their progress, how much they have achieved and what areas need further practice. The learner's attitude towards their own learning experience is positively influenced as they participate in the whole process. Evaluation also allows university teachers to reflect on the validity of their teaching practices and the types of material being used.

Typically, a variety of methods to measure expected outcomes is used. Some of these methods are formal, such as tests. But many of evaluation methods are informal; for example, questions, class discussions, etc.

In essence, evaluation takes place only when the outcomes are defined beforehand, the same about learning outcomes in the entrepreneur teaching. A grade should be given to a student for the certain task fulfilled and it should consider to what extent independently and sensibly the task has been coped with. What is more, every separate skill ought to be estimated by the teacher. The given grade should be just, stimulating, and reassuring. It should be properly commented on with a certain respect to a student. Moreover, a teacher should additionally score learners' independent progress 
and their contribution to team activities. As entrepreneurs have to be able to formulate their ideas and communicate with foreign counterparts, appropriate ways of discourse control should be chosen. It is suggested that students participate in videoconferences, meetings, and telephone talks with foreigners; take part in business role-plays; make presentations and compile the "Portfolio of an Entrepreneur". The latter could consist of a set of documents along with different independent works performed by learners both in Russian and foreign languages, such as essays, reports, case analyses, a glossary of professional terms, etc.

Evaluation is an on-going process associated with activities and methods used by educators to know when and what students are learning and to reflect on that knowledge in order to make decisions about what to do in the future.

\section{Conclusion}

Our teaching experience proves that integrating a professional foreign language course and professional disciplines, creating professionallyoriented interdisciplinary courses and applying a professionally-directed approach in teaching really form a required entrepreneur educational background, a constituent part of which is the entrepreneur's professional culture. The designed thought-provoking teaching materials build students' confidence and proficiency through systematic skills development and also encourage students to play an active role in their own leaning.

Using modern teaching technologies makes it possible to teach intercultural communication in the professional sphere and, in the long run, to foresee and overcome possible difficulties in communicating with foreign partners. Professional foreign language acquisition allows entrepreneurs to feel more confident in a foreign business environment and, thus, be more successful in business. In actual practice, the above described professional training is sure to increase their career prospects.

As for evaluation, it can help monitor student learning and should be intertwined with the teaching and learning process. Whatever evaluation methods and measures are selected, it is important for them to match the goals needed.

As it seems, teaching experience in the Nizhny Novgorod Lobachevsky University might have interest for anyone involved in the foreign language teaching of entrepreneurs. It seems to deserve attention because our alumni do their best to attract investments to our fast-growing industrial center. Certain success in their entrepreneurship is evident; even foreign business press testifies to it [20].

To sum up our experience, creating foreign professional competence as an essential part of business people cultural background is an emerging priority in today's university teaching in Russia. 


\section{References}

1. Rakitov, A.I. (2009) Science and Education. Intellectual Resources of Russia in global economy transformations. Moscow: Nauka. p. 239.

2. Megginson, L.C., Trueblood, L.R. \& Ross, G.M. (1984) Business. D.C. Heath and Company. Lexington, Massachusetts, Toronto. p. 669.

3. Bovee, C.L., Thill, J.V. \& Melson, H.M. (2007) Excellence in Business. Pearson Prentice Hall. p. 611.

4. Gural, S.K. \& Smokotin, V.M. (2014) The Language of Worldwide Communication and Linguistic and Cultural Globalization. Language and Culture. 2014. 1. p. 4-14.

5. Mitchell, P.J. (2011) English for Innovators: The Importance of ELT Provision in an Innovation Economy. Innovatika-2011. Tomsk: TSU. p. 36-40.

6. Mitchell P.J. \& Zarubin A.N. (2012) 'The English language internationally: An introduction to the case of China'. In: Gural, S.K. (ed.) Language \& culture: materials of the XXII international academic conference. Tomsk: Tomsk State University. p. 14-20.

7. Litvinyuk, A.A. (2014) Problems of formation of experts' professional competences to fit business area competence frames. International conference 'The formation of professional young entrepreneur competences during entrepreneurship training'. Moscow: Moskovskiy finansovo-promyshlenniy universitet 'Sinergia'. p. 128.

8. Education for Entrepreneurship (2011) AER Dossier. Thematic Dossier of the Assembly of European Regions. Date Views Spring. 27. p. 1-4. Available from: http://www.aer.eu (Accessed: 04.03.2016).

9. Riedl, A. \& Schelten, A. (2013) Grundbegriffe der Pädagogik und Didaktik beruflicher Bildung. Franz Steiner Verlag. Stuttgart. p. 284.

10. Lotman, U.M. (2010) What are people taught? Articles and notes. Moscow: Tsentr knigi Rudomino. p. 416.

11. Verezhagin, E.M. \& Kostomarov, V.G. (2005). Language and Culture. Moscow. p. 1308.

12. Reference for Business. (2013) Encyclopedia of Business. $2^{\text {nd }}$ ed. Cross-Cultural $/$ International Communication. Available from: http://www.referenceforbusiness.com (Accessed: 04.03.2016).

13. Terentieva, U.G. (2013) On the need to improve the competitiveness of Small Business when Russia is becoming a WTO member. Rossiyskoe Predprinimatelstvo. 17 (239). p. 126-132. Available from: http://www.creativeconomy.ru/mag (Accessed: 04.03.2016).

14. Butman, E. (2013). Entrepreneurship is a real job but not only the mindset. Kommersant Secret Firmy. 9 (334). Available from: http://www.kommersant.ru (Accessed: 04.03.2016).

15. Diamantidis, A.D. \& Chatzoglou, P.D. (2014) Employee post-training behaviour and performance: evaluating the results of the training process. International Journal of Training and Development. 18 (3). p. 149-170.

16. Gural, S.K. \& Smokotin, V.M. (2014) The Language of Worldwide Communication and Its Functional Meaning in Ethnic and National Cultures. Journal of Moscow University. Series 19: Linguistics and Crosscultural Communication. 3. p. 119-130.

17. Mitchell, P.J. \& Mitchell, L.A. (2014) Implementation of the Bologna Process and Language Education in Russia. Procedia - Social and Behavioral Sciences. 154 p. 170-174.

18. Modern educational technologies: textbook (2013). $3^{\text {rd }}$ ed. Moscow: KNORUS. p. 432.

19. Shlechty, Ph.C. (1990) Schools for the 21-st Century. Leadership Imperatives for Educational Reform. San Francisco. p. 164.

20. Wagstyl, S. (2006) Nizhny Novgorod: Striving for historic city's dream. Financial Times. $20^{\text {th }}$ April 2006. 
Information about the authors:

Kamaeva Tatyana P., Ph.D., Associate Professor, Department of English for Humanities, Department of English for Humanities, Department of Foreign Languages, Faculty of Philology, Nizhny Novgorod State University (Nizhny Novgorod, Russia). E-mail: mviazolotova@gmail.com

Kazaeva Natalia N., Ph.D., Associate Professor, Department of English for Humanities, Department of English for Humanities, Department of Foreign Languages, Faculty of Philology, Nizhny Novgorod State University (Nizhny Novgorod, Russia). E-mail: natkaz50@mail.ru

Zolotova Marina V., Ph.D., Associate Professor, Head of the Department of English for Humanities, Department of Foreign Languages, Faculty of Philology, Nizhny Novgorod State University (Nizhny Novgorod, Russia). E-mail: mviazolotova@gmail.com

Ganyushkina Elena V., Senior Lecturer, Department of English for Humanities, Department of Foreign Languages, Faculty of Philology, Nizhny Novgorod State University (Nizhny Novgorod, Russia).E-mail: elenaganyushkina@gmail.com 